\title{
Climatic Effect on Weed Management Practices in Elephant Foot Yam under High Rainfall Sub-Humid Zone
}

\author{
M. Nedunchezhiyan ${ }^{1 *}$, Biswanath $\operatorname{Sahoo}^{2}$, V. Ravi ${ }^{3}$, Kishore Sahoo ${ }^{4}$, \\ Suchismita Tripathy ${ }^{5}$, Divya bharati Sahu ${ }^{6}$, Madhuri Toppo ${ }^{2}$ and Rituparna Munshi ${ }^{7}$
}

${ }^{1}$ Regional Centre of Indian Council of Agricultural Research-Central Tuber Crops Research Institute, Bhubaneswar-751019, Odisha, India

${ }^{2}$ Krishi Vigyan Kendra (OUAT), Bhadrak, Ranital, Odisha, India

${ }^{3}$ Indian Council of Agricultural Research-Central Tuber Crops Research Institute,

Thiruvananthapuram-695017, Kerala, India

${ }^{4}$ RRTTS, Keonjhar (OUAT) -758002, Odisha, India

${ }^{5}$ Department of Agronomy, College of Agriculture (OUAT), Bhubaneswar-751003, India

${ }^{6}$ Department of Plant Breeding and Genetics, OUAT, Bhubaneswar-751003, India

${ }^{7}$ Department of Horticulture, Institute of Agricultural Science, University of Calcutta, Kolkata-700019, West Bengal, India

*Corresponding author

\section{Keywords \\ Amorphophallus paeoniifolius argentea}

\section{Article Info}

Accepted:

08 January 2020

Available Online:

10 February 2020

\section{A B S T R A C T}

A field experiment was conducted during 2016 and 2017 at the Regional Centre of Indian Council of Agricultural Research-Central Tuber Crops Research Institute, Bhubaneswar, Odisha to study the effect of climate on weed management practices in elephant foot yam [Amorphophallus paeoniifolius (Dennst.) Nicolson]. Higher average monthly maximum temperature was noticed during early crop growth period (vegetative phase) in 2017 compared to 2016. The mean minimum temperature was higher during the cropping period of 2017 compared to 2016. During 2017, Celosia argentea was observed more number and grown more vigourously compared to 2016. The weed biomass was higher during the year 2017 compared to 2016 in all weed management treatments. Higher average monthly maximum and minimum temperatures during early crop growth period (vegetative phase) favoured for more number of weeds to grow vigourously during 2017. The effect of weather was noticed more in pre (1 DAP) and post emergence (45 DAP) herbicide application treatments and weedy check. During 2016 recorded higher corm yield than 2017 irrespective of weed management practices. The weedy check treatment resulted in lower corm yield in 2017 than 2016. It can be concluded that higher rainfall and average monthly maximum temperature during crop growing period led to lower herbicide efficacy or weed management efficiency under high rainfall sub-humid zone. 


\section{Introduction}

Elephant foot yam [Amorphophallus paeoniifolius (Dennst.) Nicolson] is a starchy tuber crop. Its modified underground stem 'corm' is consumed as vegetable. The corm is used in preparation of various cuisines and reported to have medicinal properties (Misra et al., 2002; Dey et al., 2010). The corms contain glucose, galactose and rhamnose, flavonoids, phenols, coumarins, terpenoids, sterols, tannins, steroids and alkaloids (Nataraj et al., 2009; Yadu and Ajoy, 2010). Khan et al. (2008) isolated amblyone (a triterpenoid) and 3, 5-diacetylambulin (a flavonoid) from corms.

Weeds are potentially a major constraint on crop production. In humid and sub-humid tropics, weeds are major pests where adequate rainfall, temperature, and humidity favour their growth (Melifonwu, 1994). They compete with crops for natural and applied resources and are responsible for reducing quantity and quality of agricultural products (Rao et al., 2015). Elephant foot yam is susceptible to weed growth throughout the crop growth period because of little coverage by the leaf canopy.

Weeds often germinate and grow earlier than the elephant foot yam because of slow sprouting of corm setts (Nedunchezhiyan et al., 2018). Elephant foot yam is planted at wider spacing because of the canopy orientation (erect single pseudo stem with umbrella shaped canopy spread).

Weed infestation at early stage of the crop development causes severe yield reduction; up to $100 \%$ in wide spaced plantings. Weeds in elephant foot yam compete for water, nutrients, light and space below and above ground, and inhibit growth and development of the crop. Manual weeding is expensive, tedious and time consuming. Application of herbicides for weed control at pre- or postemergence can reduce dependency on manual weeding and reduce cost per weeding.

Currently very few herbicides are available for weed control, and most provide a narrow weed control spectrum (Patel et al., 2006). Information on suitable weed control for elephant foot yam in high rainfall area is not available. The investigation was therefore undertaken to study the effects of weed management practices on the yield of elephant foot yam in high rainfall areas.

\section{Materials and Methods}

A field experiment was conducted at the Regional Centre of Indian Council of Agricultural Research-Central Tuber Crops Research Institute (20 $14^{\circ} 50^{\prime \prime} \mathrm{N}$ and $85^{\circ} 47^{\prime}$ 06" E), Bhubaneswar, Odisha during 2016 and 2017. The climate of the experimental site was warm and humid in summer and cool and dry in winter.

The experiment was arranged with 3 replications in a randomized complete block design. Treatments consisted of: $\mathrm{T}_{1}$ Pendimethalin @ 1000 g/ha [1 day after planting (DAP)]+Glyphosate @ 2000 g/ha (at 90 DAP); $\mathrm{T}_{2}$ - Metribuzin @ $525 \mathrm{~g} / \mathrm{ha}$ (at 1 DAP)+Glyphosate @ 2000 g/ha (at 90 DAP), $\mathrm{T}_{3}$ - Pendimethalin @ $1000 \mathrm{~g} / \mathrm{ha}$ (at 1 DAP)+tank mix of Pyrithiobac sodium @ $62.5 \mathrm{~g} / \mathrm{ha}$ and Propiquizafop @ $62.5 \mathrm{~g} / \mathrm{ha}$ (at 90 DAP), $\mathrm{T}_{4}$-Metribuzin @ $525 \mathrm{~g} / \mathrm{ha}$ (at 1 DAP)+tank mix of Pyrithiobac sodium @ $62.5 \mathrm{~g} / \mathrm{ha}$ and Propiquizafop @ $62.5 \mathrm{~g} / \mathrm{ha}$ (at 90 DAP), $\mathrm{T}_{5}$ - Pendimethalin @ $1000 \mathrm{~g} / \mathrm{ha}$ (at 1 DAP)+2 manual weedings (at 60 and 90 DAP), $\mathrm{T}_{6}$ - Metribuzin @ 525 g/ha (at 1 DAP)+2 manual weedings (at 60 and 90 DAP), $\mathrm{T}_{7}-2$ manual weedings (at 30 and 60 DAP)+Glyphosate @ 2000 g/ha (at 90 DAP), $\mathrm{T}_{8}$ - 2 manual weedings (at 30 and 60 DAP)+tank mix Pyrithiobac sodium @ 62.5 
g/ha and Propiquizafop @ 62.5 g/ha (at 90 DAP), $\mathrm{T}_{9}$ - Weed control ground cover (WCGC), $\mathrm{T}_{10}-4$ manual weedings (at 30, 60, 90 and 120 DAP), and $\mathrm{T}_{11}$ - Control (weedy check). Farmyard manure @ 10 t/ha was uniformly incorporated before levelling in all treatments and ridges were formed at the spacing of $90 \mathrm{~cm}$.

Healthy whole corm of elephant foot yam, cv. Gajendra, weighing $400 \mathrm{~g}$, treated with cow dung slurry $(10 \mathrm{~kg}$ of fresh cow dung dissolved in $10 \mathrm{~L}$ of water and mixed with 50 g Trichoderma) one day before were planted at a $90 \times 90 \mathrm{~cm}$ spacing on ridges. The preemergence herbicides pendimethalin and metribuzin were applied one day after planting corms.

The post-emergence herbicides glyphosate, and a tank mix of pyrithiobac sodium and propiquizafop, were applied directly on weeds. Herbicides were applied without drift on elephant foot yam plants with a manually operated knapsack sprayer with a flat-fan nozzle attached to a hood using a spray volume of $500 \mathrm{~L} / \mathrm{ha}$ of water. The WCGC is a polypropylene woven fabric $\left(100 \mathrm{~g} / \mathrm{m}^{2}\right)$ which allows air and water to pass through to the soil, but suppresses weed growth.

The ground cover was spread on the ridge and furrows and the ends covered with soil. Holes were made, and corms were planted using a $10 \mathrm{~cm}$ diameter pipe. The recommended dose of fertilizers @ 120-60-120 kg/ha of N- $\mathrm{P}_{2} \mathrm{O}_{5^{-}}$ $\mathrm{K}_{2} \mathrm{O}$ was applied. The crop was planted $1^{\text {st }}$ May and harvested 31 December both the years.

Weeds were removed from 2 locations each measuring $50 \times 50 \mathrm{~cm}$ before each manual weeding and post emergence herbicide application in the respective treatments and at harvest from all treatments. Weeds were separated by species, initially sun-dried and placed in a forced air oven at $70^{\circ} \mathrm{C}$ to dry until constant weight was attained. Weed control efficiency (WCE) was calculated.

Data on weeds were subjected to square root transformation before statistical analysis. Data were analyzed using SAS (ver. 11.0, SAS Inc., Cary, NC). The data were subjected to analysis of variance. Treatment means were separated with least significant difference (LSD) (Gomez and Gomez, 1984).

\section{Results and Discussion}

During the cropping period, though there was no difference in mean maximum temperature $\left(32.8^{\circ} \mathrm{C}\right)$, but average monthly maximum temperature was varied between months in the year 2016 and 2017 (Table 1). Higher average monthly maximum temperature was noticed during early crop growth period (vegetative phase) in 2017 compared to 2016, whereas lower average monthly maximum temperature was observed during late crop growth period (maturity phase) in 2017 compared to 2016.

The average monthly maximum temperature ranged $30.1-38.8^{\circ} \mathrm{C}$ and $28.2-38.8^{\circ} \mathrm{C}$ during cropping period of 2016 and 2017, respectively (Table 1 ). The mean minimum temperature was higher during the cropping period of 2017 compared to 2016. The average monthly minimum temperature was between 15.2 and $26.4^{\circ} \mathrm{C}$ in 2016, and between 14.4 and $27.3^{\circ} \mathrm{C}$ in 2017 .

A total rainfall of $1529.2 \mathrm{~mm}$ was received during the cropping period of 2017, whereas $1241.0 \mathrm{~mm}$ in 2016 (Table 1). Mean relative humidity was $76.3 \%$ in 2016 and $76.1 \%$ in 2017. The evaporation was relatively higher in 2016 (1005.9 mm) compared to 2017 (989.8 $\mathrm{mm}$ ) during the cropping period (Table $1)$. 
Table.1 Weather during the crop growing period

\begin{tabular}{|c|c|c|c|c|c|c|c|c|c|c|}
\hline \multirow[t]{2}{*}{ Months } & \multicolumn{2}{|c|}{$\begin{array}{c}\text { Average } \\
\text { maximum } \\
\text { temperature } \\
\left({ }^{\circ} \mathbf{C}\right)\end{array}$} & \multicolumn{2}{|c|}{$\begin{array}{c}\text { Average } \\
\text { Minimum } \\
\text { temperature } \\
\left({ }^{\circ} \mathbf{C}\right)\end{array}$} & \multicolumn{2}{|c|}{$\begin{array}{l}\text { Total rainfall } \\
\quad(\mathbf{m m})\end{array}$} & \multicolumn{2}{|c|}{$\begin{array}{c}\text { Average } \\
\text { relative } \\
\text { humidity } \\
(\%)\end{array}$} & \multicolumn{2}{|c|}{$\begin{array}{c}\text { Average } \\
\text { evaporation } \\
(\mathbf{m m})\end{array}$} \\
\hline & 2016 & 2017 & 2016 & 2017 & 2016 & 2017 & 2016 & 2017 & 2016 & 2017 \\
\hline May & 38.8 & 38.8 & 26.4 & 27.3 & 114.9 & 43.1 & 63.8 & 64.0 & 221.6 & 236.9 \\
\hline June & 34.8 & 35.2 & 26.4 & 26.5 & 264.8 & 122.0 & 78.4 & 72.8 & 150.5 & 164.8 \\
\hline July & 32.2 & 31.9 & 25.8 & 25.9 & 222.2 & 445.9 & 85.3 & 85.1 & 109.6 & 94.8 \\
\hline August & 31.8 & 32.9 & 25.5 & 25.8 & 247.8 & 377.0 & 86.3 & 83.3 & 98.4 & 91.6 \\
\hline September & 31.4 & 33.6 & 25.4 & 25.7 & 238.2 & 245.2 & 86.4 & 80.9 & 99.4 & 94.7 \\
\hline October & 32.2 & 32.2 & 22.6 & 24.3 & 132.8 & 204.5 & 78.7 & 81.1 & 107.8 & 100.1 \\
\hline November & 31.0 & 29.6 & 17.4 & 18.7 & 20.3 & 55.2 & 69.0 & 72.1 & 107.5 & 100.1 \\
\hline December & 30.1 & 28.2 & 15.2 & 14.4 & 0.0 & 36.3 & 62.8 & 69.7 & 111.1 & 106.8 \\
\hline Mean/Total & 32.8 & 32.8 & 23.1 & 23.6 & 1241.0 & 1529.2 & 76.3 & 76.1 & 1005.9 & 989.8 \\
\hline
\end{tabular}

Table. 2 Weed biomass, weed control efficiency and yield of elephant foot yam as influenced by weed management practices

\begin{tabular}{|c|c|c|c|c|c|c|}
\hline & \multicolumn{2}{|c|}{$\begin{array}{l}\text { Weed biomass } \\
\left(\mathrm{g} / \mathrm{m}^{2}\right)\end{array}$} & \multicolumn{2}{|c|}{$\begin{array}{l}\text { Weed control } \\
\text { efficiency }(\%)\end{array}$} & \multicolumn{2}{|c|}{$\begin{array}{l}\text { Corm yield } \\
(\mathrm{t} / \mathrm{ha})\end{array}$} \\
\hline & 2016 & 2017 & 2016 & 2017 & 2016 & 2017 \\
\hline $\begin{array}{l}\text { Pendimethalin (1 DAP) + Glyphosate (45 } \\
\text { DAP) }\end{array}$ & 92.1 & 102.2 & 60.1 & 57.3 & 22.5 & 19.1 \\
\hline Metribuzin (1 DAP) + Glyphosate (45 DAP) & 94.4 & 107.2 & 59.1 & 55.3 & 21.5 & 19.0 \\
\hline $\begin{array}{l}\text { Pendi (1 DAP) + Tank mix of 2,4-D amine } \\
\text { salt and Quizalofop ethyl (45 DAP) }\end{array}$ & 53.6 & 57.9 & 76.8 & 75.8 & 25.1 & 23.0 \\
\hline $\begin{array}{l}\text { Metribuzin (1 DAP) + Tank mix of 2,4-D } \\
\text { amine salt and Quizalofop ethyl (45 DAP) }\end{array}$ & 55.6 & 63.2 & 75.9 & 73.6 & 24.1 & 21.2 \\
\hline $\begin{array}{l}\text { Pendimethalin }(1 \mathrm{DAP})+2 \text { rounds of } \\
\text { manual weeding }(60 \text { and } 90 \text { DAP })\end{array}$ & 44.7 & 45.2 & 80.6 & 81.1 & 29.3 & 25.2 \\
\hline $\begin{array}{l}\text { Metribuzin }(1 \mathrm{DAP})+2 \text { rounds of manual } \\
\text { weeding }(60 \text { and } 90 \mathrm{DAP})\end{array}$ & 47.6 & 48.5 & 79.4 & 79.8 & 27.2 & 23.7 \\
\hline $\begin{array}{l}2 \text { rounds of manual weeding ( } 30 \text { and } 60 \\
\text { DAP) + Glyphosate (90 DAP) }\end{array}$ & 31.5 & 37.7 & 86.4 & 84.3 & 33.4 & 30.4 \\
\hline $\begin{array}{l}2 \text { rounds of manual weeding }(30 \text { and } 60 \\
\text { DAP) + Tank mix of } 2,4-D \text { amine salt and } \\
\text { Quizalofop ethyl ( } 90 \text { DAP) }\end{array}$ & 51.5 & 59.2 & 77.7 & 75.3 & 24.6 & 22.4 \\
\hline Weed control ground cover (WCGC) & 8.2 & 11.2 & 96.4 & 95.3 & 36.0 & 32.4 \\
\hline $\begin{array}{l}4 \text { rounds of manual weeding }(30,60,90 \text { and } \\
120 \text { DAP) }\end{array}$ & 12.1 & 14.0 & 94.7 & 94.3 & 34.7 & 32.1 \\
\hline Control (No weeding) & 230.9 & 239.6 & - & - & 10.1 & 9.2 \\
\hline CD@ 5\% & 4.5 & 3.4 & - & - & 4.4 & 4.4 \\
\hline
\end{tabular}


Fig.1 Correlation between weed biomass and corm yield in elephant foot yam
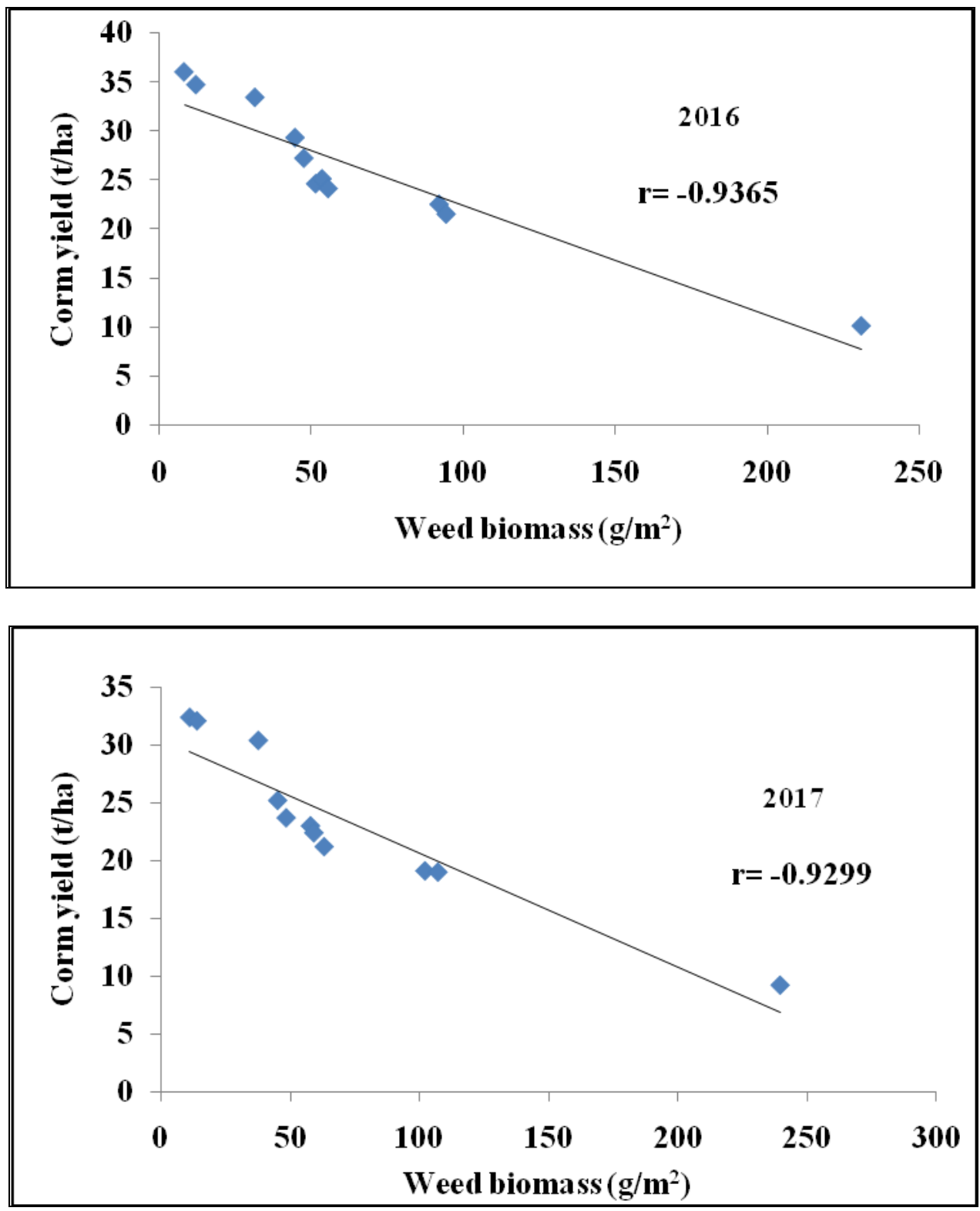

During 2016 and 2017, the major weed species observed in the elephant foot yam fields were Cyperus rotundus L. (purple nutsedge), Dactyloctenium aegypticum (L.) P. Beauv. Willd. (crowfoot grass), Digitatia sanguinalis (L.) Scop. (large crabgrass), Cyanodon dactylon (L.) Pers. (bermudagrass), Echinochloa crusgalli Beauv. (barnyard grass), Borreria hispida (L.) Schum. (shaggy button weed), Celosia argentea L. (white cockscomb), Ageratum conyzoides L. (billgoat weed), Commelina benghalensis L. (tropical spiderwort), Cleome viscosa L. (tick weed), Mimosa pudica L. (touch-me-not), and Phyllanthus niruri L (stonebreaker weed). Celosia argentea, Digitatia sanguinalis and Cleome viscosa dominated the other weed flora throughout the crop growth period. 
During 2017, Celosia argentea was observed more number and grown more vigourusly compared to 2016 due to higher rainfall especially during the month of July and August (Table 1).

The data presented in Table 2 revealed that weed biomass was higher during the year 2017 compared to 2016 in all weed management treatments. This was due to prevailing of more favourable weather for weed growth. During 2017 crop growing period, $323 \mathrm{~mm}$ higher rainfall was received than 2016 (Table 1). Further higher average monthly maximum and minimum temperatures during early crop growth period (vegetative phase) favoured for more number of weeds to grow vigourously (Table 1). Kumar et al. (2016) also reported that several flushes of weeds to emerge and grow vigourously in higher rainfall years.

The effect of weather was noticed more in pre (1 DAP) and post emergence (45 DAP) herbicide application treatments and weedy check. High rainfall in July and August months during 2017 might be reduced the efficiency of herbicides and induced multiple fleshes of weed establishment.

Weed control ground cover (WCGC) resulted in lowest weed dry matter accumulation. This was due to suppression of weed germination and emergence by WCGC owing to complete cover of the ground. The next best treatment was 4 manual weeding at 30, 60, 90 and 120 DAP. Maximum weed biomass occurred in the control treatment where weeds were not controlled.

Marked variation in weed control efficiency (WCE) was noticed among weed management practices (Table 2). The WCE was higher during 2016 than 2017 irrespective of weed management practices. This might be due to lower weed biomass production. Kumar et al. (2016) also reported that less effectiveness of weed management practices during high rainfall year due to higher weed growth under favourable weather conditions. The WCGC treatment and 4 manual weedings at 30, 60, 90 and 120 DAP, resulted in higher WCE because of lower weed biomass in both the years.

Weed management practices affected corm yield (Table 2). During 2016 recorded higher corm yield than 2017 irrespective of weed management practices owing to lower weed biomass. A higher corm yield occurred with the WCGC compared to other treatments. This was due to lower weed biomass production and higher weed control efficiency in both the years. The next best treatment was 4 manual weeding at 30, 60, 90 and 120 DAP followed by 2 manual weeding at 30 and $60 \mathrm{DAP}+$ glyphosate (at $90 \mathrm{DAP}$ ). The 4 manual weedings at 30, 60, 90 and 120 DAP and 2 manual weeding at 30 and 60 DAP+glyphosate (at 90 DAP) resulted in higher yields over the control but were lower than the ground cover treatment. Higher corm yield in these treatments indicated less interference due to weeds (Table 2). There was a negative correlation between weed biomass and corm yield during both the years of study ( $\mathrm{r}=-0.9365$ and $\mathrm{r}=-0.9299$ during 2016 and 2017, respectively) (Fig.1). Keeping weed free for longer periods may improve growth, development, and yield of elephant foot yam. The weedy check resulted in lower corm yield owing to season long crop-weed competition, which was indicated by higher weed biomass and lower WCE (Table 2). The weedy check treatment resulted in lower corm yield in 2017 than 2016.

Elephant foot yam is required well distributed optimum rainfall. Higher rainfall and average monthly maximum temperature during crop growing period led to lower herbicide 
efficacy or weed management efficiency and corm yield of elephant foot yam under high rainfall sub-humid zone.

\section{Acknowledgement}

The authors are thankful to the Head, Regional Centre of Indian Council of Agricultural Research-Central Tuber Crops Research Institute, Bhubaneswar for providing facilities to conduct the above investigation.

\section{References}

Dey, Y.N., De, S. and Ghosh, A.K. 2010. Anti-inflammatory activity of methanolic extracts of Amorphophallus paeniifolius and its possible mechanism. Int. J. of Pharma and Biosciences, $1(3): 1-8$.

Gomez, K.A. and Gomez, A.A.S. 1984. Statistical Procedures for Agricultural Research. John Wiley Sons, New York.

Khan, A., Rahman, M. and Islam, M.S. 2008. Antibacterial, antifungal and cytotoxic activities of amblyone isolated from Amorphophallus campanulatus Blume ex. Decne. Ind. J. of Pharmacology, 40 (1):41-44.

Kumar, S., Mishra, J.S., Singh, A.K., Dwivedi, S.K., Singh, S.K., Singh, S.S., Haris, A.A., Mondal, S., Bhatt, B.P., Singh, S. and Yadav, A. 2016. Response of rice (Oryza sativa) genotypes to weed management in rainfed ecosystems of eastern India. Ind.
J. of Agron, 61(1): 37-44.

Melifonwu, A.A. 1994. Weeds and their control in cassava. African Crop Science Journal, 2(4):519-530.

Misra, R.S., Nedunchezhiyan, M., T.M.S, Swamy. and Edison, S. (2002). Mass multiplication technique for producing quality planting material of Amorphophallus paeniifoilus. Tropical Science, 34:371-376.

Nataraj, H.N., R.L.N, Murthy. and Ramachandra, S. 2009. In vitro quantification of flavonoids and phenolic content of suran. Int. J. of ChemTech Res, 1(4):1063-1067.

Nedunchezhiyan, M., Laxminarayana, K. and Chauhan, V.B.S. 2018. Soil microbial activities and yield of elephant foot yam as influenced by weed management practices in Alfisols. Int. J. of Veg. Sci, 24(6): 583-596.

Patel, V.J., Upadhyay, P.N., Patel, J.B. and Meisuriya, M.I.. 2006. Effect of herbicide mixtures on weeds in Kharif maize (Zea mays L.) under middle Gujarat conditions. Ind. J. of Weed Sci, 38(1\&2):54-57.

Rao, A.N., Wani, S.P., Ramesha, M. and Ladha, J.K. 2015. Weeds and weed management of rice in Karnataka state, India. Weed Tech, 29(1):1-17.

Yadu, N.D. and Ajoy, K.G. 2010. Pharmacognistic evaluation and phytochemical analysis of the tuber of Amorphophallus paeniifolius. Int. J. of Pharma Res. and Development, 2(9):4449.

\section{How to cite this article:}

Nedunchezhiyan, M., Biswanath Sahoo, V. Ravi, Kishore Sahoo, Suchismita Tripathy, Divya bharati Sahu, Madhuri Toppo and Rituparna Munshi. 2020. Climatic Effect on Weed Management Practices in Elephant Foot Yam under High Rainfall Sub-Humid Zone. Int.J.Curr.Microbiol.App.Sci. 9(02): 985-991. doi: https://doi.org/10.20546/ijcmas.2020.902.115 